\title{
Vukodlaci - oborotnji i psoglavci u odabranoj slovenskoj prozi 19. veka
}

\begin{abstract}
AвSTRACt: Ajdačić Dejan, Vukodlaci-oborotnji i psoglavci u odabranoj slovenskoj prozi 19. veka (Werewolves and Lycanthropus in Selected Slavic Prose of the $19^{\text {th }}$ Century). "Poznańskie Studia Slawistyczne" 20. Poznań 2021. Publishing House of the Poznań Society for the Advancement of the Arts and Sciences, Adam Mickiewicz University, pp. 159-174. ISSN 2084-3011.

The author analyzes the origins and characteristics of werewolves (human-wolves) and lycanthropus (human-dogs) as dual-natured beings within Slavic folk beliefs. He also analyzes the way their mythological properties transform through literature. The werewolf's mythos is approached through texts of $19^{\text {th }}$ century authors, Russians Orest Somov (Oboroten: narodnaja skazka, 1829) and Alexander Kuprin (Serebrjanyj volk, 1901) and the Pole from Belarus Jan Barszczewski (Wilkotak, 1844), while the lycanthrope's is viewed through the lens of the literary fairy tale by Serbian Joksim Nović Otočanin (Vrzino kolo i Zlatni i Alem-grad, 1864). The author puts focus on symbolism, specifically that of the human-beast dichotomy. The literary representation of this man-beast duality in $19^{\text {th }}$ century Slavic written prose indicates a fantasy view of the coexistence between beast and man - the beastly in men, or the human in beasts.
\end{abstract}

KEYwORDS: werewolves; lycanthropus; folklore; Slavic prose; $19^{\text {th }}$ century

\section{Dvojna priroda - ljudsko i zversko}

Uverenje da postoje osobe sa dvojnom prirodom - ljudskom i životinjskom, ljudskom i biljnom, ljudskom i demonskom predstavlja tradicijom ustaljenu mitologemu ili ličnu fantazmu o proširenju ili pak ograničenju ljudskih mogućnosti. U futurističke projekcije čoveka budućnosti, po sličnom obrascu, uvodi se dvojstvo ljudskog i mašinskog. U narodnim verovanjima Slovena promena ljudskog oblika u neljudski može biti željena, nametnuta nečistom silom ili zlim čarima, a u slučaju nekog sagrešenja može biti i kazna za učinjeni greh. Folkloristkinja Olga Belova naziva dvojna bića čudovištima-poluljudima (Белова, 2000) ili poluljudima (Белова, 
2009). Kada se ljudska priroda zamenjuje dominantnom životinjskom ili demonskom prirodom, budući da se radi o živim bićima, može se govoriti i o postojanju ljudske i životinjske ili ljudske i demonske duše.

Narodna verovanja o pretvaranju čoveka u krupne zveri - medvede, vukove ili sitne životinje i insekte pojavljuju se kod svih Slovena u mnogim folklornim, dijalektološkim i etnografskim zapisima, a iscrpno ih je opisao Aleksandar Gura (Гура, 1997; 2000). O pretvaranju čoveka u vuka, kao i obratno, vuka u čoveka, tekstove su objavili Tihomir Đorđević (Ђорђевић, 1953), Ljubinko Radenković (Раденковић, 2011), Erna Pomeranceva (Померанцева, 1975), Sergej Nekljudov (Неклюдов, 1979; 2017), Ljudmila Vinogradova (Виноградова, 2004), Neonila Krinična (Криничная, 2004), Andrej Moroz (Мороз, 2000), Kazimjež Mošinjski (Moszyński, 1934), Dobroslava Venžovič-Zjolkovska i Emilija Vječorkovska (Wężowicz-Ziółkowska, Wieczorkowska, 2014), Elvira Vilčinjska (Wilczyńska, 2018), Antin Oniščuk (Онищук, 1909), Volodimir Hnatjuk (Гнатюк, 1912), Natalija Hobzej (Хобзей, 2002) i dr.

Vuk se smatra opasnom životinjom, te se stoga javlja čitav niz narodnih obreda, kalendarski utvrđenih zabrana i propisa, magijskih tekstova i postupaka usmerenih na zaštitu od stvarnih vukova (Гура, 1997, 122-159; Плас, 1999; Моро3, 2000). Drevna vera u htonske crte vukova podrazumevala je nadljudske moći pretka i njegovu sposobnost da menja oblik. Tek je kasnije u narodna verovanja uključena mogućnost magijskog pretvaranja čoveka u vuka. Rašireni nazivi za takva stvorenja u slovenskom svetu jesu: srp. vukodlak, polj. wilkołak, ukr. vovkulaka, vovkolak, vovkun, vovkorab, rus. oboroten', perevertuh, perevertyš i dr. (Гура, Левкиевская, 1995, 418; Криничная, 2004, 643-644, 693; Wilczyńska, 2018, 326-327; Раденковић, 2011, 105-106). U slovenskim jezicima se koriste adaptirani nazivi iz latinskog likantrop i iz nemačkog jezika verfulf. O vilkolaku - vukodlaku u specijalizovanim enciklopedijskim rečnicima pišu: „hybryda ludzko-zwierzęca sytuuje się na granicy świata zwierząt i ludzi, zaciera ustanowione podziały i kwestionuje tym samym porządek świata. Z tego względu jawi się jako postać tyleż niebezpieczna, co fascynująca, stanowiąc również inspirację dla twórców kultury wysokiej" (Wilczyńska, 2018, 329).

Pretvaranje u vuka, kao i svako pretvaranje, pretpostavlja premeštanje iz ljudskog sveta u „drugi”, neljudski svet. To je pojačano tradicionalnim predstavama o vezi vuka s htoničkim svetom (Раденковић, 2011, 105). 
Ruski semiotičar i folklorista Sergej Nekljudov iz šire perspektive o pretvaranju zooantropomorfnih stvorenja piše: „Мотив оборотничества базируется на комплексе архаических представлений о двойной, зооантропоморфной природе мифологических персонажей-тотемных первопредков и культурных героев” (Неклюдов, 2017, 13-14).

Veza spoljašnjeg oblika i unutrašnje prirode stvorenja sa dvojnom prirodom važna je u pričama o pretvaranju iz jednog oblika u drugi, jer je izmena izgleda u različitoj meri povezana sa promenama doživljaja samoga sebe, svoga mesta u svetu i doživljaja drugih. Voljno ili nevoljno, stečeni izgled vuka izaziva promene u viđenju sveta, koje prate i različite potrebe vuka i čoveka, kao i složeno usklađivanje dve „duše” u istom stvorenju. Mitološke predstave Slovena o vukodlacima pisci dopunjavaju i nadgrađuju u svojim autorskim književnim obradama. Ovde će biti izdvojeni postupci remitologizacije i psihologizacije u književnim renaracijama folklornih predanja o pretvaranju čoveka u vuka u prozi ruskih pisaca Oresta Somova i Aleksandra Kuprina, i u priči poljsko-beloruskog pisca Jana Barščevskog. Biće pomenuta i pojava vukodlaka u priči Srbina Svetolika Rankovića i proanalizirana slika psoglava - ljudi sa pasjom glavom - u autorskoj bajci Joksima Novića Otočanina. U verovanja narodne kulture pisci autorske književnosti unose i simbolizaciju ljudi kao viših bića u odnosu na životinje. Ali čovek nije ovladao svojim nasilnim porivima, već ih je simbolički projektovao u zveri, zaboravljajući da su grabljive životinje agresivne samo u lovu i zaštiti svoje teritorije: „Nazivanje ljudi zverima ima više socijalnih ciljeva - takvim imenom upozoravaju se moguće žrtve, utvrđuju se moralne granice ljudskog i neljudskog” (Ајдачић, 2010, 11).

\section{Oborotenj i preobražaj čoveka u vuka magijskim činima}

Magijom čudotvornih predmeta, postupaka ili reči vrač, čarobnjak može da se pretvori u vukodlaka (oborotnja), budući u vučjem obliku pribavi sebi korist i vrati se potom u ljudski vid. Ali čarobnjak može naneti i drugome zlo pretvorivši ga u vuka protiv njegove volje. U priči Oborotenj (1829, Оборотень) ruski pisac iz Ukrajine Orest Somov pripoveda o bogatom čarobnjaku koji se preobražava u vuka, njegovom posinku i dovitljivoj lepotici koja želi da sazna tajnu čarolije i uda se za čarobnjakovog posinka. 
Gogoljev prethodnik Somov priči daje podnaslov „narodna priča”, ali se ta naznaka ne tiče okvira priče sa epilogom u ironijskom duhu (Топорков, 2010). Priča o čarobnjaku, posinku i proračunatoj devojci u ironijskim okvirima priče oslanja na elemente narodnih verovanja i romantičarski „lokalni kolorit”. U uvodnom delu pisac se podsmeva korsarima, piratima, đaurima, renegatima, vampirima, koji se po mesečini prikradaju salonima osećajnih lepotica. Somov u aluzijama na pisce ne pominje začetnike gotskih romana Horasa Volpola i En Redklif, ni nemačke pesnike gotskih balada, već ismeva popularnost Bajronovih junaka, „živu četkicu” Valtera Skota, „škripavo pero” tada slavljenog ,princa romantizma”, danas zaboravljenog Viktora d'Arlenkura. On se izruguje pomodnim stranim piscima da bi pohvalio svoju svojevoljnu ,muzu” koja se smeje kroz suze i drhti od straha. Uvodni okvir priče završava rečima „U jednom selu” praćenim molbom čitaocima da ga ne pitaju kako se to selo zove i u kojoj se guberniji nalazi. U neimenovanom selu s vremena na vreme propadaju ovce, koze i jagnjad, što seljani povezuju sa „velikim-prevelikim vukom” za koga sumnjaju da je vukodlak - čovek koji se čarima pretvara u vuka. Proračunata i dovitljiva lepotica Akulina, računajući na starost i bogatstvo Jermolaja i planirajući da se uda za priglupog čarobnjakovog posinka Artjoma, nagovara momka da krišom uhodi Jermolaja i zapamti kako se on pretvara u vukodlaka. Artjom u noći punog meseca tajno uhodi starca i vidi kako on kod jednog panja izgovara basmu:

Старик Ермолай трижды обошел тихо вокруг пня и при каждом обходе бормотал вполголоса такой заговор: „На море Океане на острове Буяне, на полой поляне, светит месяц на осинов пень: около того пня ходит волк мохнатый, на зубах у него весь скот рогатый. Месяц, месяц, золотые рожки! расплавь пули, притупи ножи, измочаль дубины, напусти страх на зверя и на человека, чтоб они серого волка не брали и теплой бы с него шкуры не драли" (Сомов).

Basma iz priče o vukodlaku ne predstavalja izvorni zapis narodne basme koji je Orest Somov uneo u fikcionalni tekst, već njegovu autorsku basmu sa elementima izvorne tradicije. Ovaj tekst je docnije na neobičan način ušao u zbirke zapisa ruskih narodnih bajanja. U vreme kada je sakupljač i mistifikator ruskog folklora Ivan Petrovič Saharov sastavljao zbirku ruske narodne magije, pisac Orest Somov nije više bio živ. Saharov je basmu pretvaranja u vuka preuzeo iz pripovetke Oborotenj Somova - ne 
navodeći knjiški izvor i dodajući sitne izmene - i uključio je u zbirku Сказания русского народа о чернокнижии, objavljenu 1836. godine (Коровашко, 2009, 7, 9, 12; Топорков, 2010). Autor knjige о basmama i zakletvama u ruskoj književnosti 19. i 20. veka pokazuje kako je pisac u tobožnji magijski tekst uneo elemente prirodnog ambijenta u kome se odigrava prikazana scena:

Последующую десакрализацию места действия („на полой поляне, светит месяц на осиновый пень”) можно рассматривать как „парафраз” пейзажных деталей, содержащихся в самой повести [...] весь этот лесной интерьер создается не столько воображением писателя, сколько „предписаниями” тех поверий, которые регулируют функционирование народных представлений об оборотнях (Коровашко, 2009, 10).

„Basma oborotnja” bez upućivanja na njeno knjiško poreklo iz priče Oresta Somova ušla je u zbirku Saharova, a iz nje je kao tobože izvorni tekst prešla i u druge etnografske i folklorne zbirke, proširila se i van granica slovenskog sveta (Топорков, 2010) i ušla u nedovoljno kritičke studije o ruskim basmama. Andrej Toporkov pokazuje da je u prvi deo izmišljenog teksta pisac uneo poljanu i mesečinu kao realije ambijenta radnje sa obredom pretvaranja u vuka, a drugi posvetio zaštiti vuka od ljudi i pasa. Toporkov je kao poznavalac istočnoslovenskih bajanja ukazao na izmene koje bi piščevu basmu učinile izvornijom:

Во всем тексте о волке говорится в 3-м лице, и это вступает в определенное противоречие с заголовком - „Заговор оборотня”. Приходится допустить, что волк-оборотень говорит о себе в 3-м лице. Между тем в фольклоре и рукописной традиции имеется большое число заговоров, которые произносятся от лица волка, но при этом не описывается превращение в него; человек только метафорически отождествляет себя с волком. Как правило, такие формулы самоотождествления с волком встречаются в заговорах, которые произносили, отправляясь на суд или к какому-либо начальству, когда человеку хотелось быть сильным и побороть в себе страх. Сводку таких формул можно найти в нашей книге о рукописных заговорах. Наиболее ранний из них восходит к XV в.; он начинается словами: „Се язъ, зверь юнъ, очи мои звер[ь]и, а гроза моя царева. Блудитеся мене, крестьяне, аки овци волка”. В связи с этим „Заговор оборотня” больше соответствовал бы традиции, если бы давался с такой конъектурой: „Около пня хожу я, волк мохнатый, на зубах у меня весь скот рогатый...” (Топорков, 2010).

U priči Oresta Somova stari čarobnjak se okrenuo prema mesecu i zabio nožić sa bakarnom držaljom u panj, tri puta je poskočio i okrenuo se 
prema mesecu, posle čega je Artjom video kako je starac nestao, a umesto njega se pojavio strašni sivi vuk:

вдруг Артем видит: старика не стало, а наместо его очутился страшный серый волчище. Злой этот зверь поднял голову вверх, поглядел на месяц кровавыми своими глазами, обнюхал воздух во все четыре стороны, завыл грозным голосом и пустился бежать вон из лесу, так что скоро и след его простыл (Сомов).

Protivno uputstvima Akuline da zapamti sve što Jermolaj radi, njegov tupavi posinak sa neopravdanim uverenjem da je dobro zapamtio obred svog starog poočima pogrešno izgovara basmu kod jasikovog panja i samo se delimično pretvara u vuka. Somov se poigrava sa osobenostima dvojne prirode ,novog vukodlaka” i tvrdi kako nije čuo da su oborotnji u vučjoj koži ikada postajali pametniji no što su bili. Podsmehnuvši se nevešto izvedenom magijskim obredu i nepotpunom preobražaju „,novog oborotnja", Somov se izruguje i glupoj želji Artjoma da uplaši svoje vršnjake, što ga dovodi do opasnosti da ga seljani ubiju. Naslutivši da je „oborotenj” Artjom, Akulina zove starog Jermolaja u pomoć i ovaj sa nožićem odlazi u smočnicu u koju se sakrio ,vuk”. Stari Jermolaj kažnjava posinka izvlačenjem ušiju: „tako se bečio kako se nikada nisu kreveljili nijedna zver, niti ijedan čovek, zavijao je tako zvonko i prodorno da zamalo da ogluve i starac, i devojka, i celo selo", a potom ga oslobodi nepoželjnog vučjeg izgleda.

Nepoznavanje magijske veštine preobražaja kroz nevešto oponašanje Orest Somov je ismejao likom Artjoma, a svoju racionalističku pouku osnažio stihovima ruskog prosvetitelja Lomonosova iz njegove basne „Vuk pastir":

Я басню всю коротким толком

Хочу вам, господа, сказать

Кто в свете сем родился волком,

Тому лисицей не бывать (Сомов).

\section{Wilkołak - preobražaj u vuka i povratak u ljudski oblik}

Romantičarski pesnik i pripovedač Jan Barščevski na poljskom je jeziku, na osnovu beloruskih narodnih verovanja, napisao ciklus priča 
Szlachcic Zawalnia czyli Białoruś w fantastycznych opowiadaniach. Priče su objavljene u četiri mala toma, a priča Wilkołak objavljena je 1844. godine. U njoj pripovedač govori o susedu koji je bio pretvoren u vuka: „Nie wszystko nam w życiu zdarza się widzieć, lecz opowiem to, co słyszałem od mojego sąsiada o nieszczęśliwym człowieku, którego czarownik zamienił w wilka, i on wiele lat cierpiał, błąkając się po lasach".

Čovek po imenu Marka je susedu ispričao priču o svojoj mladosti, pretvaranju u vilkolaka, o životu u vučjoj koži i povratku ljudskom vidu. Taj tmurni čovek priča u prvom licu o svom nekadašnjem životu, o razdorima bića dvojne prirode i borbi vučje i ljudske duše, o preživljvanjima, osećanjima i dilemama. „Barščevski je jedan od prvih slovenskih pisaca koji je iskoristio najličniju formu pripovedanja kako bi prikazao krajnosti ljudskog i zverskog, ali i stepenovane prelaze između njih u životu vilkolaka” (Ајдачић, 2010, 16).

Marka i Aljona su u mladosti voleli jedno drugo, ali otac ćerki mimo njene volje izabira bogatijeg prosca Iliju. Marka ne želi da ide na svadbu svoje voljene, ali ga na to namole i na svadbi dolazi do preobražaja mladića u vuka. U svadbenom folkloru balkanskih Slovena u vreme prve bračne noći momci kao vukovi dobacuju mladencima opscene reči (Пандуревић, 2020, 33), ali ta veza ne služi kao motivacija preobražaja. U poleskom folkloru postoje verovanja da veštica može svatove da preobrazi u vukove (Гура, Левкиевская, 1995, 419). Barščevski na dva načina motiviše pretvaranje Marke u vuka - velikom tugom, jer voljenu udaju za drugoga (,,na mnie jeszcze większa napadła tęsknota") i magijskim činima sadržanim u rakiji koju gajdaš Artem daje mladiću. Vrlo brzo dolazi do promene koju zapažaju svatovi:

Nie wiele przeszło czasu, aż podchodzi do mnie mój sąsiad i patrzając mi w oczy mówi: co to znaczy, że twoje spójrzenie tak straszne jak u zwierza jakiego; drugi się odezwał: ale doprawdy jego oczy świecą się jakby wilcze, i inni blizko stojący, toż powtórzyli, patrzając na mnie jakby z przestrachem; nie wiem co się ze mną działo wtenczas zadrżałem cały; mnie się zdawało, że ci ludzie życzyli mi czegoś najgorszego.

Alona z matką blizko stojąc rozmawiała; spórzała na mnie i w przelęknieniu zakrzyczała: ach co się z nim dzieje! patrz matko, jakie straszne jego oczy (Barszczewski).

Tuga kao razlog pretvaranja mladića u vuka javlja se i u romanu $I s-$ povest savremenog ukrajinskog pisca Valerija Ševčuka (Ајдачић, 2010, 
17-18). U književnoj obradi folklornih motiva Jan Barščevski prepliće verovanja o svadbi kao vremenu pogodnom za zle čari sa likom zlog svirača koji čarima izaziva kobni preobražaj. Kazivač govori kako je najpre pobegao kući, a kada ga pas nije poznao, a susedov sin mu rekao da su mu lice i ruke obrasli dlakom, on beži u šumu. Kazivač se seća svojih nekadašnjih muka, teškog privikavanja na novi život i napora da vučja priroda ne prevlada ljudsku. U vučjem obliku sa ljudskim svojstvima, ali odbačen od ljudi i bez mogućnosti da im se približi, mladić je počeo da mrzi ljude i da im čini štetu, uključujući i otmicu deteta vinovnika svoje nesreće. Kada vilkolak uz pomoć čarobnice Aksinje nakratko povrati svoj ljudski oblik, obuzima ga griža savesti i on počinje da ljude spasava od šumskih zveri, da bi se na kraju pretvorio u čoveka.

Barščevski koristi narodna demonološka predanja, verovanja u magiju, kako usmerenu zlu tako i dobrobitnu magiju, ali ih povezuje sa psihološkom motivacijom svog junaka, odstupajući od mitologije i uvodeći racionalističko tumačenje ljudske sudbine. Junak Barščevskog nije učinio nikakav greh zbog koga je pretvoren vuka. Krivac za njegov nesrećni preobražaj pripisuje se zlom gajdašu čarobnjaku koji ga je začarao rakijom. Ali pisac pokazuje da je za povratak ljudskom stanju i telu za vilkolaka bila odlučujuća želja da ponovo postane čovek koji bira između zla i dobra.

\section{Srebrni vuk - preobražaj}

U uvodnoj sceni „božićne” priče Srebrni vuk (Серебряный волк) ruski pisac Aleksandar Kuprin u ime mladog gospodina u prvom licu opisuje svoj dolazak na železničku stanicu Vučja u južnom delu Bjaloveške prašume. I naslov i ime stanice najavljuju da će priča biti povezana sa vukovima. Putnika čeka kočijaš Trohim i oni po tihoj i svetloj decembarskoj noći kreću sankama koje vuku dva konja. Kada se iz šume čuje udaljeni zvuk nalik plaču, kočijaš potvrdi da to mogu biti vukovi, ali možda i vukodlaci.

Ну да, вовкулак. Бывают, чуете, такие люди, что умеют волками перекидываться. Вот они и бегают по лесам и трубят. У нас на Полесье этой погани богацько. Там за разных водяных и лесных чертяках, за видьм и за видьмаков, я не знаю, чи тому правда, чи ни. Може, одни бабьи сплетки. А вовкулаки у нас водятся - то правда (Куприн). 
Kočijaš, začuvši zavijanje vukova, govori da su razni đavoli, možda i bapske izmišljotine, ali da priče o vukodlacima nisu sujeverja, jer u njihovom kraju vukodlaci zaista postoje. Pripovedač uz dijalekatsku reč вовкулак u napomeni navodi i poznatije ruske nazive вурдалак і упырь. Kočijaš počinje da kazuje polesko predanje o veselom, preduzimljivom i druželjubivom Stecku koji se iz vojske vratio potpuno izmenjen. Istinitost priče kazivač utvrđuje opaskom da Stecka znaju svi u Kazimirki, te da je on bio stric starca koga i kočijaš i njegov putnik poznaju. Stecko, „crn, mršav, kao smrt, s prevezanom desnom rukom, hrom na levu nogu” otpušten je iz vojske posle rata sa Turcima sa dve medalje i dva turska metka u telu. Roditelji su ga najpre molili, pa preklinjali da se oženi, ali je on to odbio. Tek na bespogovorni pritisak majke da neće ni jesti ni piti dok se ne oženi, on pristane. Ali na svadbi nije ni poljubio svoju nevestu. Njegova žena se docnije žali da sa njom ne razgovara i ne spava, a da noću odlazi od kuće. Otac, misleći da sin odlazi drugim ženama, odluči da ga krišom prati. Ali na svoj užas on vidi da kroz kapiju na ulicu istrčava ogroman, beli, srebrni vuk. Steckov otac prati šepavog srebrnog vuka i vidi je on vođa vučjeg čopora. U očajanju, sa suzama u očima on beži kući, gde ga čeka sin: „,- Постой, батька. Ты думаешь, я не знаю, что ты за мною следом бегал! Ну, так поди завтра в церковь и отслужи молебен за то, что живой назад вернулся. Если бы не я - разорвали бы тебя на мелкие кусочки и умер бы ты без покаяния" (Куприн).

Stecko ocu kaže i da će zauvek otići iz njihovog kraja i da se nikada više neće vratiti. A na kraju ocu otkriva tamnu tajnu o svom prokletstvu i muci: „И поверь: чья душа проклята свыше - нелегко ему на свете жить”. U ovoj kratkoj priči sa brzim raspletom, u kojoj se pisac i ne vraća okvirnoj situaciji kočijaševog pričanja, ne navode se prilike koje su dovele do Steckove promene i njegovog prokletstva. Čitaocu su kočijaš i pisac saopštili da se ta promena desila u ratu sa Turcima, ali oni čitaocima ostavljaju da domisle ulogu rata u ozverenju čoveka i zlom usudu mladića koji se u ratu pretvorio u srebrnog vuka. Stecko je kao vuk pre konačnog odlaska spasao oca od neminovne smrti, ali on više ne pripada ni svojoj vrsti ni zajednici, već drugom svetu, svetu zveri.

U božićnoj priči kao popularnom časopisnom žanru u kojoj se prikazuju strašni događaji, Kuprin je istinitost priče utvrdio ličnim svedočenjem pripovedača i kazivača o preobražaju čoveka u srebrnog vuka i pobedi 
zverskog nad ljudskim. Taj postupak usmenih kazivača koriste pripovedači koji se uživljavaju u njihovu ulogu.

\section{Spomeni vukodlaka}

U govorima južnih Slovena postoji više arealno stabilizovanih naziva za vukodlaka, pri čemu se u srpskim govorima delimično preklapaju nazivi vukodlak i vampir, ali u nekim krajevima dominira jedan od njih (Плотникова, 2004, 212-217). U leksikografskoj i folklorističkoj tradiciji klasičan je zapis objavio Vuk Karadžić na stranicama Srpskog rječnika (1818): „Vukodlak se zove čovjek u koga (po pripovijetkama narodnijem) poslije smrti 40 dana uđe nekakav đavolski duh, i oživi ga (povampiri se). Po tom vukodlak izlazi noću iz groba i davi ljude po kućama i pije krv njihovu" (Караџић, 1818).

Karadžić dalje opisuje kako se pošten čovek može povampiriti ako preko njegovog mrtvog tela preleti ptica, te objašnjava kako po narodnim verovanjima kocem ubijaju vukodlaka, govori o sposobnosti vukodlaka da se provuče i kroz „najmanju rupicu” (Караџић, 1818). I u potonjim etnografskim zapisima 19. veka vukodlaci se izjednačavaju sa pokojnicima koji oživljavaju noću i plaše ljude. Oni su aktivni noću, kako je u dalmatinskom zaleđu početkom 20. veka zapisao Vladimir Ardalić u Bukovici: „Oni bazaju i tumaraju, otkad se smrkne, pa dok ne počnu pijevci pjevati i Zdrava Marija zvoniti; onda se oni vraćaju u svoje grobove" (Ardalić, 1908/1994).

Karadžićev Srpski rječnik, kao i njegovi ogledi o bićima iz narodnih verovanja u godišnjaku Danica, sakupljeni potom u odeljku „Vjerovanje stvari kojijeh nema" u knjizi Život i običaji naroda srpskog, nose tragove hercegovačkog porekla poznatog leksikografa i folkloriste. U zapadnim i južnim govorima oživljenog pokojnika nazivaju vukodlak, pa je tako naslovljena i Karadžićeva rečnička odrednica, dok od reči vampir iz istočnih govora vodi uputnica na reč vukodlak. U istočnim krajevima vampiri ne moraju nužno da se preobražavaju u vukove i ne moraju da imaju vučji izgled. Kada je Šumadinac Milovan Glišić o Savi Savanoviću pisao priču „Posle devedeset godina”, on nije koristio reč vukodlak, već vampir, koja se sreće i u drugim njegovim pričama u gogoljevskom stilu folklornog realizma. Kod srbijanskih pisaca 19. veka retko se javlja vukodlak, 
a poimenično ih kao vampira i vukodlaka pominje Svetolik Ranković u priči „Jesenje slike”. Ranković ih razdvaja kao nečista bića kako bi opisao jezovitost gluvog noćnog doba, „najstrašnijeg vremena”:

Prolazi ponoćno doba, a sa njim i njegove strahote. A kako je strašna seoska ponoć!... To je doba kad se pojavljuju najveća strašila na svet i rade što hoće, sve dok prvi petli ne objave zoru. Tada ti se izvlače mršavi vampiri iz groblja, vukodlaci iz jazbina, vile iz gore, veštice iz odžaka, drekavci iz potoka i svaka prokleta utvar, što radi o glavi čovečijoj. To je najstrašnije vreme. [...] Čuje se već gromoviti avaz drekavca... Po brdima jure vampiri i trče u selo... Na livadi, pod osojem, već se uhvatilo kolo vila, a po raskrsnicama se već šunjaju vukodlaci (Ранковић).

\section{Psoglavi}

U Srpskom rječniku Vuka Karadžića narodna verovanja su nekada predstavljena širokim opisima, kao npr. u slučaju objašnjavanja značenja reči vještica, vukodlak, a reč psoglav sadrži samo prevod na nemački i latinski kojima je dodat izraz „I psoglava koji doma nema” (Караџић, 1818). Pasoglav ili psoglav je u verovanjima slovenskih naroda „divlji čovek s pasjom glavom i s jednim okom nasred čela, predstavnik psoglavih naroda-ljudoždera koji žive u dalekoj zemlji” (Раденковић, 2011, 418). Psoglavi žive u mračnoj zemlji, u močvarama ili šumama (Раденковић, 2011, 418; Белова, 2000, 52-53; Белова, 2009, 158). U narodnu kulturu Slovena su predstave o psoglavima ušle iz starogrčkih predstava o dalekoj Indiji posredstvom apokrifa, Aleksandride, srednjovekovnih spisa u vizantijskim i latinskim prevodima.

U listu za zabavu i književnost Danica, koji je u Novom Sadu uređivao Đorđe Popović, objavljena je 1864. godine bajkovita povest Vrzino kolo i zlatni i Alem-grad. Joksim Nović Otočanin u dvanaest nastavaka pripoveda o svetu ,neznaboštva” i pustolovinama junaka Bjelokose i grabancijaša Poznana. U priči o borbi dobra i zla Bjelokosa upoznaje razne svetove seleći se u snu pomoću čudotvornog nožića. On sreće divove koji se pretvaraju u patuljke, grabancijaše, aždahe, troglavog zmaja, „lavčovjeka”, vile i druga bića koja imaju poneka svojstva preuzeta iz folklora. U trećem nastavku Bjelokosa, koji još ne poznaje pravila kretanja između svetova, opisuje svoj boravak u zemlji psoglava („Danica” 1864, br. 16, 244-249). Pisac iz narodne tradicije koristi ime psoglavi i ukazuje na njihov veliki 
rast, nazivajući psoglava ,poludžinom”. Sveznajući pripovedač prikazuje psoglava kao pritvorno stvorenje koje se pravi da manje zna o drugim svetovima no što zna (,činjaše se i nevješt”). Psoglav govori Bjelokosi da je čuo da postoje ljudi „koji nose različne glave na ramenima” - mačije, „pasije”, „tičije”, orlove. Pripovedač svet psoglava naseljava egzotičnim biljkama i životinjama - tamo rastu kedrovi i silne palme, a pored jelena ima belih slonova. Takvo prikazivanje blisko je srednjovekovnim i apokrifnim tekstovima o Dalekom istoku. U odnosu prema nenadanom gostu Bjelokosi, psoglav koji se predstavlja imenom Dub gostoprimljiv je i poziva ga u svoj dom: „No ako si gladan i žedan, mogu te ponuditi da sa mnom pođeš eto do prvih naših staništa, pak ćeš se častiti, koliko ti srce ište. Šta imamo, to ne tajimo od naših gostiju". Nović Otočanin u prikazivanju psoglava koristi dve suprotne strategije - on ističe njihove razlike u odnosu na ljude, ali, s druge strane, pokazuje sličnosti, uz naglašavanje nekih osobenosti psoglava. Budući da u svetu psoglava vlada velika žega, kuće nemaju pregrada i sa svih strana su otvorene. Slično ljudima, žene psoglava prave rukotvorine koje pripovedač veoma hvali. Različitost u odnosu na svet ljudi predstavlja mnogoženstvo psoglava i veliki broj dece.

Pisac u odnosu Bjelokose kao čoveka prema psoglavima ističe odbojnost i gađenje koje Bjelokosa prikriva. Najpre on saznaje da će, ako ne ode iz njihove zemlje za par dana, tačnije do mladog meseca, morati da se oženi psoglavkom (,odmah mu pođe ladan znoj niz leđa”). Bjelokosi se gadi i da jede i pije iz istog čanka sa psoglavima:

Čudno je bilo Bjelokosi ručati iz jednog čanka sa psoglavom, jer pasija glava ostaje pasija i gadna je u takome poslu [...] Psoglav je pio to piće iz duboka čanka, a Bjelokosa ga je pio iz istoga i gadio se, kako se samo može pomisliti, ali je morao u silu piti, da se ne zamjeri svome dobrom domaćinu, koji ga je primio krasno i dočekao svojski (Новић Оточанин, 1864, 246).

Bjelokosa se putovanjem u snu vrati kući pre no što bi morao da se oženi psoglavkom. U načinu prikazivanja psoglava pisac se nije oslanjao na ljudožderske crte psoglava u narodnoj tradiciji, kao ni na uverenja da oni imaju samo jedno veliko oko. Joksim Nović Otočanin je egzotizovao svet prirode psoglava kao daleki i žarki predeo, a njihov socijalni život je učinio drukčijim uvođenjem mnogoženstva i čudnih običaja vezanih za prinudnu ženidbu. 


\section{Zaključak}

Dvojna priroda čoveka i vuka ima mitološka, fantazmatska i simbolička značenja. Kada osoba kontroliše svoju dvojnu prirodu i po potrebi menja svoj izgled, ona to čini sebi u korist, ali ako je voljno ili nevoljno prinuđena da prebiva u drugom obliku, onda ona trpi, budući da je svesna podele u sebi na dve prirode, dve duše.

Kada su se slovenski pisci 19. veka oslanjali na mitološke motive i likove slovenskog folklora, oni su ih nadgrađivali i koristili unoseći u tradicionalne narodne predstave autorska viđenja, dodajući drukčije motivacije - kako u preobražaj čoveka u vuka i obratno tako i u prikaz isprepletenog zverskog i ljudskog identiteta. Potreba za pričom o dvojnosti čoveka u fantaziji pisaca racionalističkog 19 . veka obraća se narodnim verovanjima kako bi posredstvom lika oborotnja u priči Oresta Somova, vilkolaka Jana Barščevskog ili srebrnog vuka Aleksandra Kuprina promislila i predstavila sapostojanje zverskog i ljudskog u čoveku. Ovi pisci prespituju kako čovek prihvata zver u sebi ili kako zver pronalazi u sebi ono što je čovečno, osvetljavajući na taj način simbolički predstave o ljudskoj agresivnosti i krvoločnosti. Promena koja se dešava pomeranjem ka ljudskom ili zverskom vodi ka promeni pogleda na svet, vodi patnji zbog gubitka ljudskog oblika, borbi za očuvanje ljudskog u biću koje je psihički podeljeno.

\section{Izvori}

Barszczewski, J. (1844). Szlachcic Zawalnia czyli Białoruś w fantastycznych opowiadaniach. Petersburg: W Drukarni Karola Kraja.

Караџић, В. С. (1818). Српски рјечник. http://raskovnik.org/. 10.09.2020.

Куприн, А. (1901). Серебряный волк. Оборотень (Полесская легенда). „Одесские новости” бр. 5230, 4.03.1901. http://az.lib.ru/k/kuprin_a_i/text_1560.shtml. 10.09.2020.

Новић Оточанин, J. (1864). Врзино коло и златни и Алем-град, „Даница” бр. 16, str. 244-249.

Ранковић, С. Јесење слике, Приповетке, str. 2-30. http://www.antologijasrpskeknjizevnosti.rs/ASK_SR_AzbucnikPisaca.aspx. 10.09.2020.

Сомов, О. (1829). Оборотень. http://az.lib.ru/s/somow_o_m/text_0030.shtml. 10.09.2020. 
[Karadžić, V. S. (1818). Srpski rječnik. http://raskovnik.org/. 10.09.2020.

Kuprin, A. (1901). Serebryany volk. Oboroten' (Poleskayja legenda). „Odeskie novosti" br. 5230, 4.03.1901. http://az.lib.ru/k/kuprin a i/text 1560.shtml. 10.09.2020.

Nović Otočanin, J. (1864). Vrzino kolo i zlatni i Alem-grad, „Danica” br. 16, str. 244-249.

Ranković, S. Jesenje slike. Pripovetke, str. 2-30. http://www.antologijasrpskeknjizevnosti.rs/ASK_SR_AzbucnikPisaca.aspx. 10.09.2020.

Somov,O.(1829). Oboroten'. http://az.lib.ru/s/somow_o_m/text_0030.shtml. 10.09.2020].

\section{Literatura}

Ardalić, V. (1908/1994). Bukovica. Narodni život i običaji. https://www.rastko.rs/antropologija/ardalic_bukovica/index.html. 12.09.2020.

Moszyński, K. (1934). Kultura ludowa Stowian, t. 2, z. 1. Kraków: Polska Akademia Umiejętności.

Wężowicz-Ziółkowska, D., Wieczorkowska, E. (red.). (2014). Wilki i ludzie. Małe kompendium wilkologii. Katowice: Grupakulturalna.pl.

Wilczyńska, E. (2018). Wilkołak. U: Polska bajka ludowa, t. 3. Red. V. Wróblewska. Torun: Wydawnictwo UMK, str. 326-329.

Ајдачић, Д. (2010). Оборотењ (човек-вук) у источнословенским књижевностима. „Речи” бр. 3, str. 11-23.

Белова, О. (2000). Представления о монстрах-полулюдях в народной традиции славян. U: Миф в культуре: человек - не-человек. Ред. Л. А. Софронова, Л. Н. Титова. Москва: Индрик, str. 47-57.

Белова, О. (2009). Полулюди. U: Славянские древности. Этнолингвистический словарь, књ. 4. Ред. Н. И. Толстой. Москва: Международные отношения, str. $156-159$.

Виноградова, Л. (2004). Оборотничество. U: Славянские древности. Этнолингвистический словарь, књ. 3. Ред. Н. И. Толстой. Москва: Международные отношения, str. 466-471.

Гнатюк, В. (1912). Знадоби до української демонології. „Етнографічний збірник” књ. 33-34, бр. 1-2, str. 34-280.

Гура, А. (1997). Символика животных в славянской народной традиции. Москва: Индрик.

Гура, А. (2000). Демонологические свойства животных в славянских мифологических представлениях. U: Славянский и балканский фольклор: Народна демонология. Ред. Л. Н. Виноградова, Е. Е. Левкиевская, С. М. Толстая. Москва: Индрик, str. 303-313.

Гура, А., Левкиевская, Е. (1995). Волколак. U: Славянские древности. Этнолингвистический словарь, књ. 1. Ред. Н. И. Толстой. Москва: Международные отношения, str. 418-420. 
Ђорђевић, Т. Р. (1953). Вампир и друга бића у намем народном веровағу и предању. Београд: Српска академија наука.

Коровашко, А. (2009). Заговоры и заклинания в русской литературе $X I X-X X$ веков. Москва: Intrada.

Криничная, Н. (2004). Оборотни. Русская мифология. Мир образов фольклора. Москва: Гаудеамус.

Мороз, А. (2000). Волк в южнославянской народной культуре. Человеческое и демоническое. U: Миф в культуре: человек-не-человек. Ред. Л. А. Софронова, Л. Н. Титова. Москва: Индрик, str. 78-86.

Неклюдов, С. (1979). О кривом оборотне (к исследованию мифологической семантики фольклорного мотива), U: Проблемы славянской этнографии. К 100-летию со дня рождения Д. К. Зеленина. Ред. К. В. Чистов, А. К. Байбурин. Ленинград: Наука, str. 133-140.

Неклюдов, С. (2017). Оборотничество: »природа вещей«, объем понятия, региональные версии. In Umbra: Демонология как семиотическая система. Альманах, књ. 5. Отв. ред. Д. И. Антонов, О. Б. Христофорова, str. 13-33. https:// liber.rsuh.ru/elib/000012732. 12.09.2020.

Онищук, А. (1909). Матеріали до гуиульскої демонологї. „Матеріали до україньскої етнології” књ. 11, бр. 2, str. 1-139.

Пандуревић, J. (2020). Фолклорни еротикон. Еротика и поетика српских народних пјесама. Вишеград: Андрићев институт.

Плас, П. (1999). Неколико аспеката симболике вучјих уста у српским обичајима и веровањима. „Кодови словенских култура” бр. 4, str. 184-212.

Плотникова, А. (2004). Этнолингвистическая география южной Славии. Москва: Индрик.

Померанцева, Э. (1975). Мифологические персонажи в русском фольклоре. Москва: Наука.

Раденковић, Љ. (2011). Пасоглав, псоглав. U: Словенска митологија. Енииклопедијски речник. Ред. С. М. Толстој, Љ. Раденковић. Београд: Zepter Book World, str. 418-419.

Топорков, А. (2010). Русский волк-оборотень и его английские жертвы. „НЛО” бр. 103, str. 140-151. https://magazines.gorky.media/nlo/2010/3/russkij-volkoboroten-i-ego-anglijskie-zhertvy.html. 12.09.2020.

Хобзей, Н. (2002). Гуиульська міфологія. Етнолігвістичний словник. Львів: s. n.

[Ajdačić, D. (2010). Oborotenj (čovek - vuk) u istočnoslovenskim književnostima. „Reči” br. 3, str. 11-23.

Belova, O. (2000). Predstavlenija o monstrah-poluljudjah v narodnoj tradicii slavjan. U: Mif v kul'ture: čelovek - ne-čelovek. Red. L. A. Sofronova, L. N. Titova. Moskva: Indrik, str. 47-57.

Belova, O. (2009). Poluljudi. U: Slavjanskie drevnosti. Ètnolingvističeskij slovar', knj. 4. Red. N. I. Tolstoj. Moskva: Meždunarodnye otnošenija, str. 156-159.

Ben'kovskij, I. (1894). Rasskaz o vovkulakah. „Kievskaja starina” br. 12, str. 495497. 
Hnatjuk, V. (1912). Znadoby do ukrajins'koji demonolohiji. „Etnohrafičnyj zbirnyk” knj. 33-34, str. 34-280.

Gura, A., Levkievskaja, E. (1995). Volkolak. U: Slavjanskie drevnosti. Ėtnolingvističeskij slovar', knj. 1. Red. N. I. Tolstoj. Moskva: Meždunarodnye otnošenija, str. 418-420.

Gura, A. (1997). Simvolika životnyh v slavjanskoj narodnoj tradicii. Moskva: Indrik.

Gura, A. (2000). Demonologičeskie svojstva životnyh v slavjanskih mifologičeskih predstavlenijah. U: Slavjanskij i balkanskij fol'klor: Narodna demonologija. Red. L. N. Vinogradova, E. E. Levkievskaja, S. M. Tolstaja. Moskva: Indrik, str. 303313.

Đorđević, T. R. (1953). Vampir i druga bića: u našem narodnom verovanju i predanju. Beograd: Srpska akademija nauka.

Korovaško, A. (2009). Zagovory i zaklinanija v russkoj literature XIX-XX vekov. Moskva: Intrada.

Kriničaja, N. (2004). Oborotni. Russkaja mifologija. Mir obrazov fol'klora. Moskva: Gaudeamus.

Moroz, A. (2000). Volk v južnoslavjanskoj narodnoj kul'ture. Čelovečeskoe i demoničeskoe. U: Mifv kul'ture: čelovek - ne-čelovek. Moskva: Indrik, str. 78-86.

Nekljudov, S. (1979). O krivom oborotne (k issledovaniju mifologičeskoj semantiki fol'klornogo motiva). U: Problemy slavjanskoj ètnografii. K 100-letiju so dnja roždenija D. K. Zelenina. Red. K. V. Čistov, A. K. Bajburin. Leningrad: Nauka, str. $133-140$.

Nekljudov, S. (2017). Oborotničestvo: „priroda veŝej”, ob"em ponjatija, regional'nye versii. U: In Umbra: Demonologija kak semiotičeskaja sistema. Al'manah, br. 5. Otv. red. D. I. Antonov, O. B. Hristoforova, str. 13-33. https://liber.rsuh.ru/ elib/000012732. 12.09.2020.

Onyščuk, A. (1909). Materialy do hucul'skoji demonolohiji. U: „Materialy do ukrajin'skoji etnolohiji" knj. 11, br. 2, str. 1-139.

Pandurević J. (2020). Folklorni erotikon. Erotika i poetika srpskih narodnih pjesama. Višegrad: Andrićev institut.

Plas, P. (1999). Nekoliko aspekata simbolike vučjih usta u srpskim običajima $i$ verovanjima. „Kodovi slovenskih kultura” 4, str. 184-212.

Plotnikova, A. (2004). Ėtnolingvističeskaja geografija južnoj Slavii. Moskva: Indrik.

Pomeranceva, È. (1975). Mifologičeski personaži v russkom fol'klore. Moskva: Nauka. Radenković, Lj. (2011). Pasoglav, psoglav. U: Slovenska mitologija. Enciklopedijski rečnik, Red. S. M. Tolstoj, Lj. Radenković. Beograd: Zepter Book World, str. 418-419.

Toporkov, A. (2010). Russkij volk-oboroten' i ego anglijskie žertvy. „NLO” br. 103, str. 140-151. https://magazines.gorky.media/nlo/2010/3/russkij-volk-oboroten-i-ego-anglijskie-zhertvy.html. 12.09.2020.

Vinogradova, L. (2004). Oborotničestvo. U: Slavjanskie drevnosti. Ėtnolingvističeskij slovar', knj. 3. Red. N. I. Tolstoj. Moskva: Meždunarodnye otnošenija, str. 466471.

Hobzej, N. (2002). Hucul's 'ka mifolohija. Etnolihvistyčnyj slovnyk. L'viv: s. n.]. 